International Journal of Life Sciences
Available online at http://sciencescholar.us/journal/index.php/ijls
Vol.3 No. 1, April 2019, pages: $56 \sim 70$
e-ISSN: 2550-6986, p-ISSN: 2550-6994
https://doi.org/10.29332/ijls.v3n1.273

\title{
Local Decomposer Increase Composting Rate and Produce Quality Rice Straw Compost
}

\author{
I Nengah Muliarta a , I Gusti Ayu Mas Sri Agung b , I Made Adnyana c , I Wayan Diara d \\ Article history: Received 18 July 2018, Accepted: 31 December 2018, Published: 9 April 2019
}

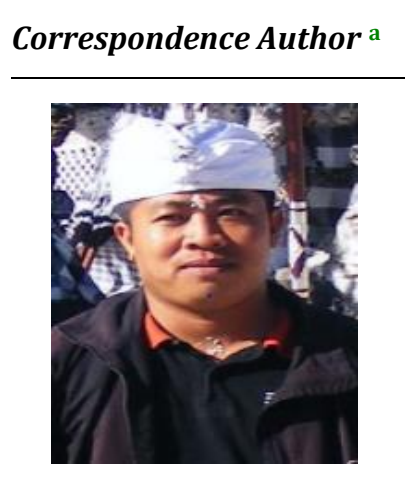

Keywords

compost quality; composting rate; enumeration; local decomposers; rice straw;

\begin{abstract}
This study at aiming to examine the ability of Balinese local decomposers in composting rice straw. Another goal is to examine the composting rate and quality of compost in enumeration rice straw that is not enumerated. The study used 2 combinations of local decomposers and comparative decomposers. The local decomposer 1 combination consists of Paenibacillus polimyxa, Pseudomonas flourescens, and Trichoderma hazianum. The combination of local decomposers 2 consists of Pseudomonas flourescens, Trichoderma hazianum, and Aspergilus niger. Comparative decomposers are commercial decomposers consists of Azospirillum, Aspergillus, Actinomycetes, Lactobacillus, Pseudomonas, and yeast. The study was conducted in Tangkas Village, Klungkung on June 17 up to July 23, 2017. The study used a Randomized Block Design (RBD) with 3 (three) replications. Composting is conducted for 35 days and compost reversal is conducted every 7 days. The results showed that the addition of local decomposer 1 was able to provide a $\mathrm{C} / \mathrm{N}$ ratio of up to 13.78 , local decomposers 2 to 14.80 and this result was not significantly different from the comparison decomposition $\mathrm{C} / \mathrm{N}$ ratio which reached 15.31 .
\end{abstract}

e-ISSN: 2550-6986, p-ISSN: 2550-6994@ Copyright 2019. The Author. SS Journals Published by Universidad Técnica de Manabí. This is an open-access article under the CC BY-SA 4.0 license (https://creativecommons.org/licenses/by-sa/4.0/) All rights reserved.

\section{Contents}

Abstract

a Doctorate Student Program of Agricultural Science, Faculty of Agriculture, Udayana University, Jl. PB. Sudirman, Denpasar, Bali, Indonesia

b Lecturer in Doctorate Program of Agricultural Science, Faculty of Agriculture, Udayana University, Jl. PB. Sudirman, Denpasar, Bali, Indonesia

c Lecturer in Doctorate Program of Agricultural Science, Faculty of Agriculture, Udayana University, Jl. PB. Sudirman, Denpasar, Bali, Indonesia

d Lecturer in Doctorate Program of Agricultural Science, Faculty of Agriculture, Udayana University, Jl. PB. Sudirman, Denpasar, Bali, Indonesia 


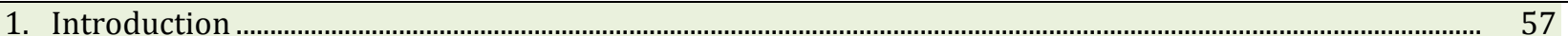

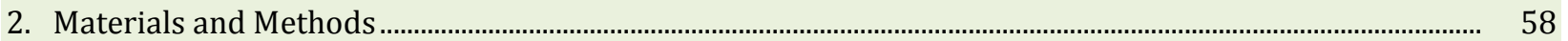

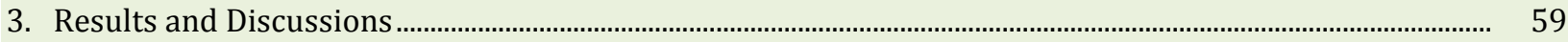

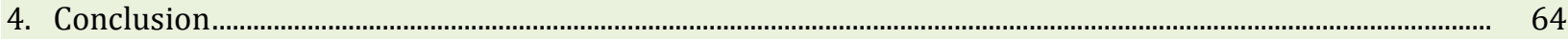

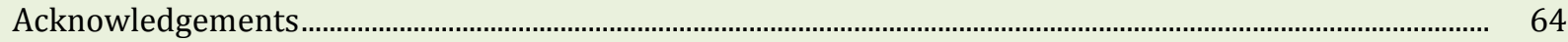

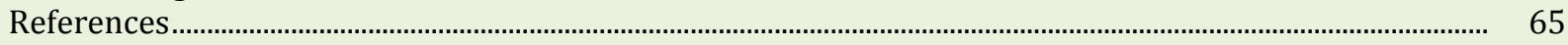

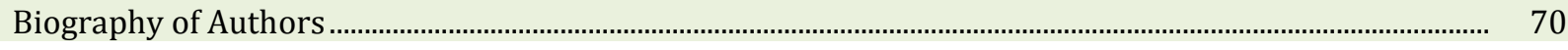

\section{Introduction}

The use of compost is part of an effort to reduce production costs due to the purchase of inorganic fertilizers. The use of compost is not only to reduce the need for inorganic fertilizers but also to reduce environmental pollution (Sarwar et al., 2007). It can be used as an alternative to inorganic fertilizers to increase crop production (Wanatabe et al., 2009; Palanivell et al., 2013). The rice straw is a potential for local raw materials that can be processed into organic fertilizer. The amount at harvest is very abundant and has not been utilized optimally (Zhao et al., 2014). In every $1 \mathrm{~kg}$ of grain produced 1-1.5 kg of rice straw (Binod et al., 2010).

The results of various studies show that rice straw consists of nutrients included $\mathrm{N}, \mathrm{P}, \mathrm{K}$ and C-organic which is needed by the soil. Rice straw contains about $0.6 \% \mathrm{~N}, 1.5 \% \mathrm{~K}, 5 \% \mathrm{Si}, 40 \% \mathrm{C}, 0.10 \% \mathrm{P}$ and $\mathrm{S}$ respectively (Ponnamperuma, 1984). Returning rice straw to paddy fields through a decomposition process can be an option for farmers to use agricultural waste with environmentally friendly technologies and efforts to reduce fertilizer costs (Gaind \& Nain, 2011). Composting of the rice straw and its utilization on agricultural land serves to maintain the content of soil organic matter and soil microbiological properties (Goyal et al., 2009). Erses et al., (2008), argued that aerobic composting can be an option due to the decomposition process is faster than anaerobic and becomes an effort in reducing methane emissions.

In order to speed up the composting process can be conducted by adding a decomposer, the one is a combination of the local decomposers. The use of local decomposers in an effort to utilize local resources around farmers. The decomposers function is to stimulate the decomposition process due to they consist of bacteria and enzymes (Sadik et al., 2010). The choice of decomposers must also pay attention to compost raw material in the form of rice straw included lignocellulose (cellulose, hemicellulose, and lignin). The content of cellulose, hemicellulose, and lignin in the material provides an opportunity to use lignocellulotic microbes to accelerate the decomposition process (Nur et al., 2008; Sethi et al., 2013; Saini et al., 2015; Shruti et al., 2015). The decomposition of lignocellulose material can be conducted by lignocellulose microbes consisting of fungi, bacteria, and actinomycetes. Several groups of microorganisms such as clostridium, cellulomonas, trichoderma, penicillium, neurospora, fusarium, aspergillus, etc, have high cellulolytic and hemicellulolytic activity (Chandel et al., 2007).

Reducing the size of compost material at enumerating compost material is expressed as a means of accelerating the composting process (Bending \& Turner, 1999). The enumeration of lignocellulose material will make it easier for microbes to decompose lignocellulose material (Nazhad et al., 1995). Atalia et al., (2015), argued that compost material for composting with natural aeration can be cut into pieces about 1-5 $\mathrm{cm}$.

The studies on composting of the rice straw with the addition of decomposers have been conducted, other researchers. Yaacob et al., (2017), composting rice straw using fungi of Trichoderma harzianum. Goyal \& Sindhu (2011), composted rice straw using a consortium of three fungi (Aspergillus awamorii, Paecilomyces fusisporous and Trichoderma viride). Sitepu et al., (2017), conducted composting of rice straw by adding Aspergillus niger LD 137 and Trichoderma viride LD 140. Research on composting rice straw by utilizing local decomposers, especially Balinese local decomposers, had not been done. Therefore, this research needed to be completed.

The stability and maturity of compost have become an important parameter for evaluating the quality of compost in the United States (Brewer \& Sullivan, 2001). The C/N ratio can be used as a reference for estimating compost maturity (Harada et al., 1981). The chemical indicators commonly used to assess the stability and maturity of compost included the content of organic matter, dissolved organic carbon, the ratio of

Muliarta, I. N., Agung, I. G. A. M. S., Adnyana, I. M., \& Diara, I. W. (2019). Local decomposer increase composting rate and produce quality rice straw compost. International Journal of Life Sciences, 3(1), 56-70. https://doi.org/10.29332/ijls.v3n1.273 
$\mathrm{C} / \mathrm{N}$, ammonia and nitrate, $\mathrm{pH}$ and electrical conductivity (Wichuk \& McCartney, 2010). The parameters measured in this study is temperature, water content, $\mathrm{C} / \mathrm{N}, \mathrm{N}, \mathrm{P}, \mathrm{K}$, organic $\mathrm{C}, \mathrm{pH}$, composting rate and percentage decrease mass.

\section{Materials and Methods}

Composting of the rice straw (Ciherang variety) was conducted using 3 types of decomposers (Local 1, Local 2 and comparative decomposers). Local decomposers 1 are a combination of Paenibacillus polimyxa, Pseudomonas flourescens, and Trichoderma hazianum. Local Decomposer 2 is a combination of Pseudomonas flourescens, Trichoderma hazianum, and Aspergillus niger. Paenibacillus polimyxa decomposer (isolated from rhizosphere plant), Pseudomonas flourescens (isolated from rhizosphere onion), and Trichoderma hazianum (isolated from the dung of cow) is a collection of Laboratory of Plant Diseases, Faculty of Agriculture, Universitas Udayana. Aspergillus niger decomposer (isolated from Bali chicken manure) is a collection of the Bali Institute of Agricultural Technology (BPTP). Comparative decomposers (positive controls) use commercial decomposers produced by PT Indo Acidatama Tbk. which consists of Azospirillum, Aspergillus, Actinomycetes, Lactobacillus, Pseudomonas, and yeast. The decomposer dose used was $20 \mathrm{ml}$ for $20 \mathrm{~kg}$ of the rice straw.

In this study, Randomized Block Design (RBD) is used with 3 (three) replications. The treatments that were tried were types of decomposers (local decomposer 1, local 2 and comparison) and straw enumeration (nonenumerated and enumerated) which were arranged factorially (Table 1). The composting tank uses a gunny sack with a diameter of $75 \mathrm{~cm}$ and a height of $110 \mathrm{~cm}, 35$ days of composting and compost reversal every 7 days.

Table 1

Treatment was tried in this study

\begin{tabular}{lcccc}
\hline \multicolumn{1}{c}{ Treatment } & $\begin{array}{c}\text { Non } \\
\text { decomposer }\end{array}$ & Local decomposer 1 & $\begin{array}{c}\text { Local } \\
\text { decomposer 2 }\end{array}$ & $\begin{array}{c}\text { Comparative } \\
\text { decomposer }\end{array}$ \\
\hline Not enumerated & NDUC & D1UC & D2UC & CDUC \\
Enumerated & NDCC & D1CC & D2CC & CDCC \\
\hline
\end{tabular}

The variables observed included compost temperature, decomposition rate, moisture content, $\mathrm{C} / \mathrm{N}, \mathrm{pH}$, organic $\mathrm{C}, \mathrm{N}, \mathrm{P}$, and $\mathrm{K}$ compost, compost weight, and weight loss of compost during composting. The speed of composting or the rate of decomposition during composting is calculated using equations (Olson, 1963; Sari et al., 2016).

$$
\mathrm{R}=\frac{W 0-W t}{T}
$$

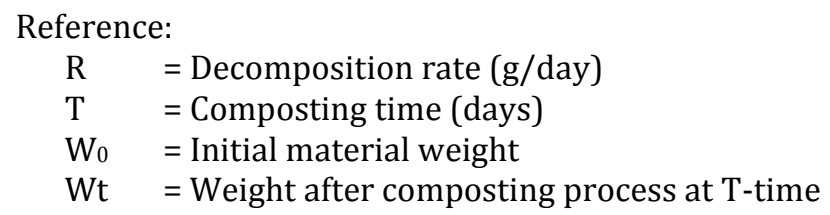

The weight of the compost and the weight loss of the compost are obtained at weighing the final weight and then looking for the difference between the initial weight and the final weight. The percentage of weight loss during the composting process is calculated according to the equation (Olson, 1963; Sari et al., 2016):

$$
\mathrm{W}=\frac{W 0-W t}{W 0} \times 100 \%
$$

Reference:

$$
\mathrm{W}=\text { Decomposition percentage (\%) }
$$


$\mathrm{W}_{0} \quad$ = Initial material weight

$\mathrm{Wt} \quad=$ Weight after composting process at T-time

Analysis

Data obtained were analyzed by variance (ANOVA) followed the smallest real difference (SRD) test at the level of $5 \%$ with COSTAT and MSTAT Computer software.

\section{Results and Discussions}

The comparison of the results of the composting process with the addition of decomposers and enumeration shows the rate of composting and decrease in compost mass, it is presented in Table 2.

Table 2

The effect of decomposers and enumeration of materials on composting rates and percentage loss of compost mass

\begin{tabular}{|c|c|c|c|c|c|}
\hline Treatment & $\begin{array}{c}\text { Composting } \\
\text { rate } \\
\text { (kg/day-1) }\end{array}$ & $\begin{array}{c}\text { Percentage } \\
\text { of mass } \\
\text { loss }(\%)\end{array}$ & $\begin{array}{c}\text { Water } \\
\text { content } \\
(\%)\end{array}$ & $\begin{array}{l}\text { Total of compost } \\
\text { microbes } \\
(\mathrm{cfu} / \mathrm{ml})\end{array}$ & $\begin{array}{c}\mathrm{pH} \\
\text { compost }\end{array}$ \\
\hline \multicolumn{6}{|l|}{ Decomposer } \\
\hline Non decomposer & $0,067^{b}$ & $12,83^{\mathrm{b}}$ & $43,17^{a}$ & $1,43 \times 10^{8 b}$ & $7,50^{a}$ \\
\hline Local decomposer 1 & $0,088^{a}$ & $15,833^{\mathrm{a}}$ & $43,33^{\mathrm{a}}$ & $1,36 \times 10^{8} \mathrm{~b}$ & $7,63^{a}$ \\
\hline Local decomposer 2 & $0,083^{a}$ & $15,833^{\mathrm{a}}$ & $43,17^{a}$ & $2,24 \times 10^{8} \mathrm{a}$ & $7,43^{\mathrm{a}}$ \\
\hline Comparative & $0,088^{a}$ & $15,667^{\mathrm{a}}$ & $43,00^{\mathrm{a}}$ & $2,19 \times 10^{8}$ a & $7,81^{\mathrm{a}}$ \\
\hline \multicolumn{6}{|l|}{ Decomposer } \\
\hline SRD 5\% & 0,0133 & 2,1399 & - & 0,190 & - \\
\hline \multicolumn{6}{|l|}{ Enumeration } \\
\hline Without enumerated & $0,074^{b}$ & $12,917^{b}$ & $43,17^{a}$ & $1,49 \times 10^{8 b}$ & $7,65^{\mathrm{a}}$ \\
\hline Enumerated & $0,089^{a}$ & $17,177^{a}$ & $43,17^{a}$ & $2,12 \times 10^{8}$ a & $7,54^{\mathrm{a}}$ \\
\hline SRD 5\% & 0,0094 & 1,5132 & - & 0,134 & - \\
\hline
\end{tabular}

Reference: The numbers followed by the same letters in the treatment, in the same column, are not significantly different from the SRD 5\% test

Based on the results of the study showed that the composting rate in composting rice straw ranged from $0.067-0.089 \mathrm{~kg} /$ day. The lower results were obtained by Adawiyah et al., (2017), who obtained decomposition rates ranging from 11.2-16.2 gr/day when composting waste with the addition of bacterial isolates from the landfill and with composting time for 30 days. The composting rate in the control was recorded at 0.067 $\mathrm{kg} /$ day, the composting rate was thought to occur due to the role of the decomposers already contained in the rice straw. This allegation is in line accordance viewing of Strom \& Finsstein (1994), stated that decomposer microbes found in nature have the ability to compost. Statistically, the composting rate in the control (composting without decomposers) was lower or significantly different compared to the addition of decomposer treatment $(\mathrm{p}<0.05)$. This is thought to occur due to the combination of added decomposers can work synergistically with the decomposer contained in the material. It is to guess is in accordance with a viewing of Tsigarida et al., (2003) and viewing of Mitri \& Foster (2013), who argued that the addition of a microbial association or a single microorganism can have a positive, negative, or neutral response with other microorganisms present in the same material. While the composting rate in the treatment of the addition of local decomposers does not look different compared to the comparison. It indicates that the local decomposer combination used has the same decomposition rate as the comparative decomposer.

The addition of local decomposers and comparators also gave a higher decrease in mass compared to controls. This is presumably due to the addition of decomposers accelerates the decomposition process, therefore, the compost mass decreases. This result is in accordance with the opinion that composting is substantially part of efforts to reduce waste mass (Larney et al., 2000; Tiquia et al., 2002; Breitenbeck \& Muliarta, I. N., Agung, I. G. A. M. S., Adnyana, I. M., \& Diara, I. W. (2019). Local decomposer increase composting rate and produce quality rice straw compost. International Journal of Life Sciences, 3(1), 56-70. https://doi.org/10.29332/ijls.v3n1.273 
Schellinger, 2004). However, according to Michel et al., (2004), the reduction in the mass of material during composting is strongly influenced by the moisture. The moisture (moisture content) of compost at the end of composting obtained in the study generally is still in accordance with standard national Indonesia (SNI) 197030-2004 standards, it is recommended a maximum humidity of 50\%. The moisture of compost decreases during the composting period due to the degradation of waste by microbial activity that produces heat. Therefore, the temperature becomes high (Kadir et al., 2016). The moisture percentage will also decrease by adding time intervals and is a positive sign to evaluate the stability of compost. Decreasing the percentage of moisture provides a more stable and mature compost (Ameen et al., 2016).

The compost turns out to also provide a faster composting rate and a higher decrease in mass compared to without enumeration. This condition occurs due to the microbial activity is related to particle size, wherein, the smaller particle sizes make it easier for microbes to access the substrate (Atalia et al., 2015; Roman et al., 2015). The enumeration of lignocellulose material will make it easier for microbes to decompose lignocellulose material (Nazhad et al., 1995). Theoretically, it is true that the smaller particle size is better the biological degradation (Bertoldi et al., 1983).

In this study, the total microbial compost of rice straw obtained ranged from $1.36 \mathrm{x} 10^{8} \mathrm{cfu} / \mathrm{ml}$ to $2.19 \mathrm{x}$ $10^{8} \mathrm{cfu} / \mathrm{ml}$. The total microbial results obtained are in accordance with the statement of Chandna et al., (2013), stated that the microbial population of compost ranged from $10^{5}$ to $10^{9} \mathrm{cfu} \mathrm{g}^{-1}$ compost. The results of analysis of variance showed that the total microbes in the control were the same as the treatment of the addition of local decomposers 1 , however, the different from the total microbes in the treatment of addition of local decomposers 2 and comparators. The enumeration treatments have made microbes easier to decompose (Atalia et al., 2015). The presence of microbes acts to degrade organic matter, especially, those containing sugar, carbohydrates, and protein. Microbes both bacteria and fungi utilize organic matter as an energy source for growth (Streminska \& Raviv, 2016). The microbial diversity will increase when the decomposition process takes place and the quality of the substrate decreases (Dilly et al., 2004). According to Streminska \& Raviv (2016), the microbial activity is regulated by the heat produced and the quality of organic matter. These factors also affect the number and diversity of microbes at each stage of composting.

During the composting process, the highest temperature was recorded at $57.40^{\circ} \mathrm{C}$ occurred in the D1CC treatment on the $4^{\text {th }}$ day. The optimal temperature for composting not enumerated occurred on the $11^{\text {th }}$ day, with a maximum temperature of $45.57^{\circ} \mathrm{C}$ and occurred in the D2UC treatment. In the study, Dhal et al., (2012), obtained a maximum composting temperature of 57.3 $\mathrm{C}$. In another experiment, Makan et al., (2013), obtained a maximum composting temperature of $47^{\circ} \mathrm{C}$. The increased temperatures during composting were due to the activity of microorganisms in degrading agricultural waste. The increased temperature is influenced by the availability of the amount of oxygen in the compost pile in aerobic composting (Abdel-Aziz, 2014). Composting with an optimal temperature range of $45-65^{\circ} \mathrm{C}$ will produce mature compost in 4-6 weeks (Sondang et al., 2014). The description of temperature changes during the composting process, it is presented in Figure 1.

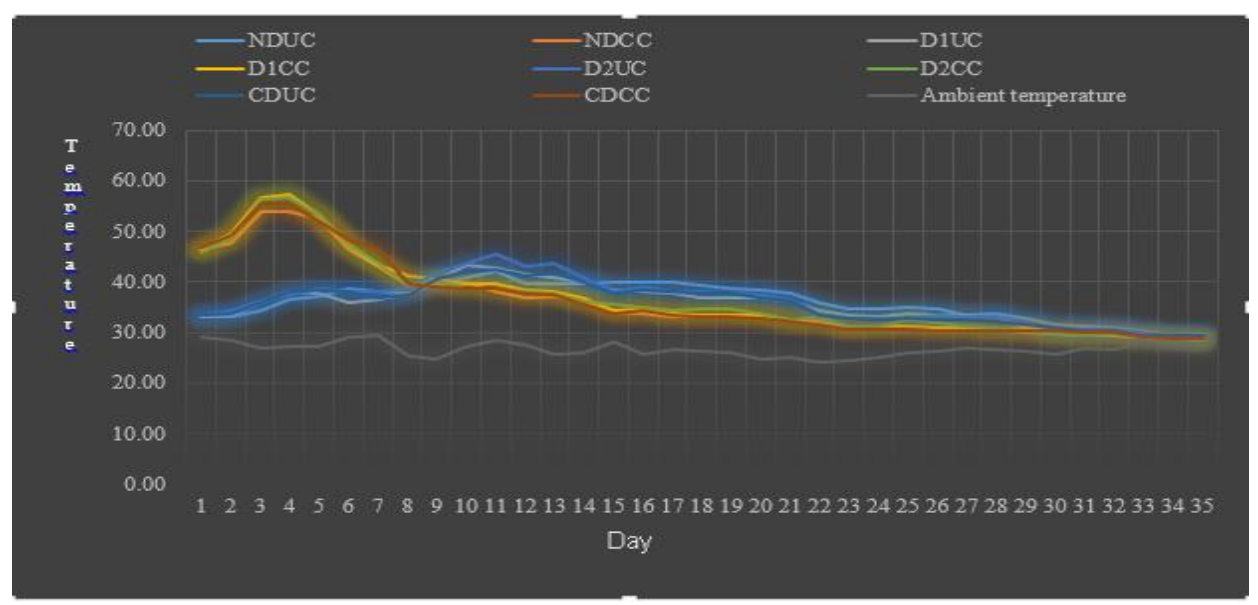

Figure 1. The change in temperature during the composting process 
According to Tuomela et al., (2000), when the temperatures exceed 55 to $60^{\circ} \mathrm{C}$, microbial activity down drastic. While the optimum temperature for thermophilic mushrooms is $40-50^{\circ} \mathrm{C}$, it is also the optimum temperature for lignin degradation in compost. The combination of temperatures above $40^{\circ} \mathrm{C}$ and $\mathrm{pH}$ below 6 is a combination of conditions that greatly inhibit the composting process (Sundberg, 2005). The condition of acid $\mathrm{pH}$ affects inhibiting the composting process, due to it inhibits microbial respiration rate and decreases the rate of degradation (Wang et al., 2015; Ameen et al., 2016). During the composting process, the lowest pH was recorded in all enumerated straw treatments reached a value of 5 , it occurs on the $3^{\text {rd }}$ and $4^{\text {th }}$ days. Lowering $\mathrm{pH}$ value about 5.0 or less due to the formation of organic acids (Atalia et al., 2015; Roman et al., 2015). The initial stage of composting, $\mathrm{pH}$ is acidified by the formation of organic acids. In the thermophilic phase, due to the conversion of ammonium to ammonia, $\mathrm{pH}$ rises until finally stabilizes at near neutral values (Roman et al., 2015). The description of changes in $\mathrm{pH}$ during the composting process is presented in Figure 2.

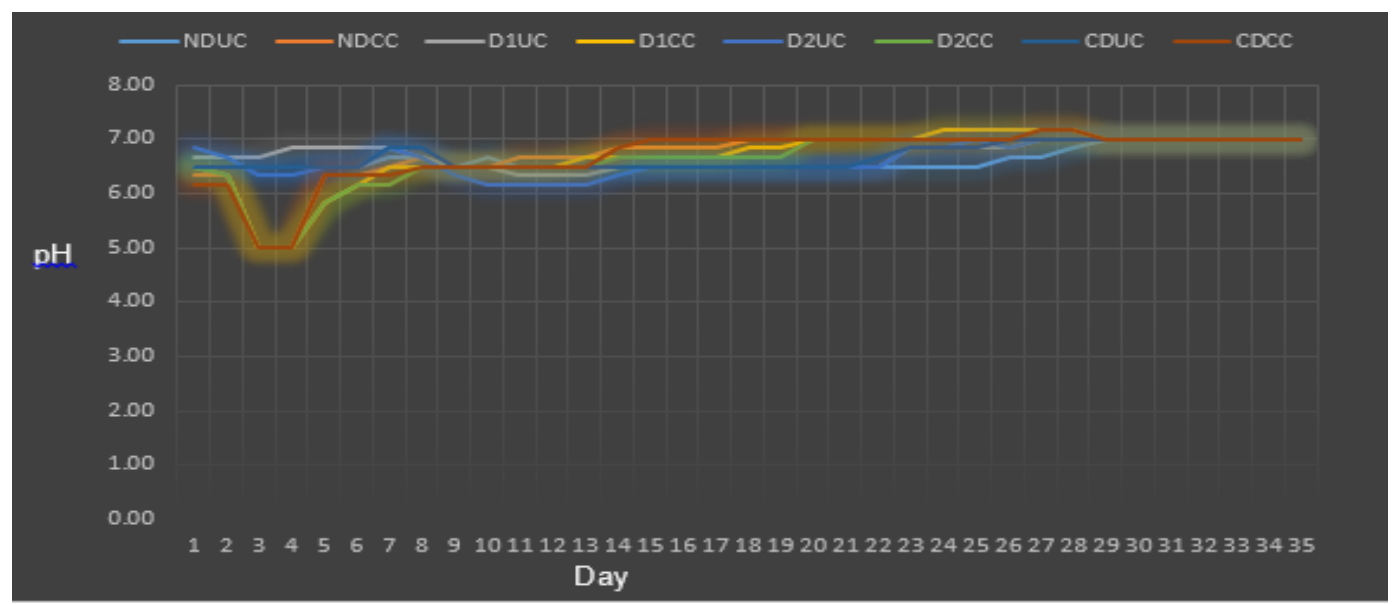

Figure 2. The change of $\mathrm{pH}$ during the composting process

The acidity $(\mathrm{pH})$ of rice straw compost obtained in this study ranged from 7.5-7.81. If it is compared with the SNI standard, $\mathrm{pH}$ value of rice straw compost is seen above the SNI standard, it requires a pH of 6.80-7.49. This result is in accordance with a viewing of Fuchs et al., (2016), that the pH value of compost is usually relatively high around 7.2-8.5. Based on the technical requirements of organic solid fertilizer listed in the Minister of Agriculture Regulation No. 70/Permentan/SR.140/10/2011 concerning Organic Fertilizers, Biofertilizers, and Soil Improvement. It is stated that $\mathrm{pH}$ of solid organic fertilizers ranges from 4-9.

The results of the analysis of straw compost an average water content of 11.36 found the characteristics of rice straw compost is presented in Table 3.

Table 3

The effect of decomposers and enumeration of materials on the characteristics of compost produced

\begin{tabular}{lccccc}
\hline \multicolumn{1}{c}{ Treatment } & C/N ratio & $\begin{array}{c}\text { C- organic } \\
(\%)\end{array}$ & $\begin{array}{c}\text { N-total } \\
(\%)\end{array}$ & $\begin{array}{c}\mathrm{P} \\
(\%)\end{array}$ & $\begin{array}{c}\mathrm{K} \\
(\%)\end{array}$ \\
\hline Decomposer & & & & & \\
Non composer & $20,08^{\mathrm{a}}$ & $29,70^{\mathrm{a}}$ & $1,49^{\mathrm{b}}$ & $0,192^{\mathrm{b}}$ & $4,01^{\mathrm{b}}$ \\
Local decomposer 1 & $13,78^{\mathrm{b}}$ & $26,16^{\mathrm{b}}$ & $1,90^{\mathrm{a}}$ & $0,270^{\mathrm{a}}$ & $4,77^{\mathrm{a}}$ \\
Local decomposer 2 & $14,80^{\mathrm{b}}$ & $26,36^{\mathrm{b}}$ & $1,80^{\mathrm{a}}$ & $0,252^{\mathrm{a}}$ & $4,87^{\mathrm{a}}$ \\
Comparative decomposer & $15,31^{\mathrm{b}}$ & $24,67^{\mathrm{b}}$ & $1,77^{\mathrm{a}}$ & $0,248^{\mathrm{a}}$ & $4,68^{\mathrm{a}}$ \\
SRD 5\% & 2,148 & 3,288 & - & 0,0478 & 0,3653 \\
Enumeration & & & & & \\
Without enumerated & $15,28^{\mathrm{a}}$ & $26,36^{\mathrm{a}}$ & $1,74^{\mathrm{a}}$ & $0,224^{\mathrm{a}}$ & $4,64^{\mathrm{a}}$ \\
Enumerated & $16,71^{\mathrm{a}}$ & $27,08^{\mathrm{a}}$ & $1,74^{\mathrm{a}}$ & $0,257^{\mathrm{a}}$ & $4,53^{\mathrm{a}}$ \\
\hline
\end{tabular}

Muliarta, I. N., Agung, I. G. A. M. S., Adnyana, I. M., \& Diara, I. W. (2019). Local decomposer increase composting rate and produce quality rice straw compost. International Journal of Life Sciences, 3(1), 56-70. https://doi.org/10.29332/ijls.v3n1.273 


\begin{tabular}{llllll}
\hline$S R D 5 \%$ & - & - & - & - & -
\end{tabular}

Reference: The numbers followed by the same letters in the treatment, in the same column, are not significantly different from the SRD 5\% test

The highest content of C compost was in the control (without additional decomposers) reached 29.70\%. The results of statistical analysis showed that the $\mathrm{C}$ compost in the control was significantly different $(\mathrm{p}<0.05)$ with $\mathrm{C}$ compost in the addition of decomposer treatment. Higher $\mathrm{C}$ content in the control showed a slower degradation process compared to the treatment with the addition of decomposers. The change in $\mathrm{C}$ content reflect degradation of organic matter due to the microbial activity, wherein, $\mathrm{C}$ decreases due to oxidation to CO2 (Wu et al., 2010; Tiquia et al., 2002). The carbon is an energy source for microbes and nitrogen is needed for the synthesis of protoplasm (Kalatzi et al., 2016; Kadir et al., 2016). During the early stages of composting, the use of metabolic carbon is much higher than nitrogen, which causes a decrease in the $\mathrm{C} / \mathrm{N}$ ratio (Wu et al., 2010).

The highest ratio of $\mathrm{C} / \mathrm{N}$ compost was found in the control treatment with values reaching 20.08. Based on the technical requirements of organic solid fertilizers listed in the Minister of Agriculture Regulation No. 70/Permentan/SR.140/10/2011 concerning Organic Fertilizers, Biofertilizers, and Soil Improvement. It is stated that the ratio of $\mathrm{C} / \mathrm{N}$ to solid organic fertilizer can range from 15-25. The ratio of $\mathrm{C} / \mathrm{N}$ compost in the control can reach the required standard, presumably due to the rice straw and water used when composting already contains decomposer microbes. This assumption is in accordance with Lee (2016), viewed that microorganisms naturally occur in all organic matter, water, air, and soil so that the diversity of microorganisms is high. Microorganisms unlike bacteria, fungi, and Actinomycetes act as decomposers. According to Rishell (2013), naturally, microbes found on the surface of the material can degrade compost material. Streminska \& Raviv (2016), revealed that it is difficult to generalize the presence of microbes in composting raw materials. Due to it is controlled by a number of factors, i.e., the type of organic matter, water content, and temperature. In the study, Stella \& Emmyrafedziawati (2015), found a microbial consortium consisting of 30 types of bacteria have the ability to degrade cellulose, hemicellulose, and lignin found in the soil. The microbial consortium is believed to be able to accelerate and increase the degradation of the rice straw in the composting process. Sirisena \& Manamendra (1995), identified two strains of cellulolytic bacteria from rice straw i.e., Listeria sp. \& Enterobacter sp. has an important role during the early stages of composting. In addition, about $85-99 \%$ of bacteria cannot be cultivated with known culture techniques in the laboratory (Hongoh \& Toyoda, 2011; Stewart, 2012; Lok, 2015). Bacteria do not grow in laboratory standard media tend to play an important role in the cycle of carbon, nitrogen, and other elements, and have an impact on the organism and the surrounding environment (Stewart, 2012).

Statistically, the ratio of $\mathrm{C} / \mathrm{N}$ control was significantly different $(\mathrm{p}<0.05)$ if it is compared to the addition of decomposer treatment. This means that the combination of decomposers added can accelerate the process of decomposition of organic matter, thus, providing a lower ratio of $\mathrm{C} / \mathrm{N}$ than controls. This result is in accordance with the viewed of Nuraini (2009) and Sadik et al., (2010), stated that the decomposers function to stimulate the decomposition process due to they consist of bacteria and enzymes. This is due to the decomposers are microbial isolates have the special ability to digest organic matter, therefore, they decompose quickly (Chheda et al., 2016).

The other studies also found that the addition of decomposers was able to provide better compost maturity. Sadik et al., (2010), stated that the addition of decomposers to composting agricultural wastes (leftover vegetables, fruit, and animal waste) gave a lower ratio of $\mathrm{C} / \mathrm{N}$ than controls (without decomposers) in the composting time of 35 days. Wherein, the ratio of $\mathrm{C} / \mathrm{N}$ compost with the addition of a decomposer is 15 and without additional decomposers of 19 . However the results of the $\mathrm{C} / \mathrm{N}$ ratio obtained are not accompanied by statistical analysis, so that, the differences can be found to be significantly different or not. Nuraini (2009), claimed to get different results when composting rice straw using M-Dec decomposers (Trichoderma sp., Aspergillus sp., and Trametes sp.) with reversals every 7 days. The compost with the M-Dec decomposer produces C/N 15 and controls (without M-Dec) 21, but the composting time is 2 months. Yaacob et al., (2017), when composting rice straw using fungi of Trichoderma harzianum. The treatment with additional decomposers Trichoderma harzianum produces compost with a ratio of C/N 17.5 and control of 28.7. However, composting was conducted within 90 days and rice straw was soaked in water for 24 hours before composting. 
The $\mathrm{N}$ content obtained in this study is still in accordance with SNI which gives a minimum limit of $\mathrm{N}$ content of $0.40 \%$. This result is also in accordance with a viewing of Herity (2003), stated that the $\mathrm{N}$ total range in compost is 1-3\%. Statistically, the $\mathrm{N}$ content in controlling was significantly different compared to the addition of decomposer treatment $(\mathrm{p}<0.05)$. The $\mathrm{N}$ content of compost with the addition of decomposer treatment seems to have a higher $\mathrm{N}$ content than control. This is happened due to the role of decomposers added, specifically the role of $\mathrm{N}$ binding bacteria. The activity of nitrogen-fixing bacteria is common at the end of composting (Bishop \& Godfrey, 1983). Paenibacillus polymyxa is not only one of the phosphorus solvent bacteria but also has the ability to perform $\mathrm{N}$ fixation (Lal \& Tabacchioni, 2009).

In general, the P content in all treatments is very in accordance with the SNI which gives a minimum limit of $0.1 \%$. The results of the statistical analysis, the $\mathrm{P}$ content in the control was significantly different if it is compared with the addition of decomposer treatment $(\mathrm{p}<0.05)$. The P content of compost with the addition of decomposer treatment was higher than the control occurred due to the role of the decomposer added. Pseudomonas fluorescens is one of the bacteria that has the ability to dissolve phosphate (Soesanto et al., 2011; Alemu, 2013) and is also ideal as a biofertilizer (Oteino et al., 2015). There are also Paenibacillus polymyxa bacteria which in addition have the ability to degrade lignocellulose also have the ability to dissolve phosphate and nitrogen fixation (Weselowski et al., 2016). Aspergillus niger is one of the fungi have the ability to provide phosphorus for plants (Salih et al., 1989). There is also a fungus from the genus Trichoderma $s p$. which in addition to being a solvent $\mathrm{P}$ is also a biological controlling agent (Kapri \& Tewari, 2010). One of them is Trichoderma harzianum which has the ability as a potential phosphorus solvent (Tallapragada \& Gudimi, 2011).

In composting rice was obtained compost with $\mathrm{K}$ content in accordance with SNI requires a minimum limit of $0.20 \%$. Statistically, the K content in the control was significantly different from the addition of decomposer treatment $(\mathrm{p}<0.05)$. In addition to the effects of the mineralization process, the presence of microbial $\mathrm{K}$ solvents in the decomposer combination added was thought due to the $\mathrm{K}$ content in the decomposer addition treatment to be higher than control. Aspergillus is one of the fungi that has the ability as a solvent $\mathrm{K}$ (Assad et al., 2010). Increased levels of $\mathrm{K}$ are also thought to be caused by the presence of $\mathrm{K}$ solvent bacteria, namely bacteria from the genus Pseudomonas sp. (Parmar et al., 2016) and $\mathrm{K}$ solvent bacteria from the genus Paenibacillus sp. (Liu et al., 2012).

Generally, the addition of a combination of local decomposers 1 and 2 gives a higher ratio of $\mathrm{C} / \mathrm{N}$, higher content of C-organic, $\mathrm{N}, \mathrm{P}$, and $\mathrm{K}$. It means that the combination of decomposers 1 and 2 can provide better compost quality. However, the combination of local decomposers 1 and 2 gives results that are not significantly different compared to commercial decomposers. The results indicate that the combination of local decomposers 1 and 2 have the same degradation capability.

The treatment of rice straw enumeration in composting for 35 days did not provide different compost maturity. Composting with enumerated compost, with a size of $2-5 \mathrm{~cm}$ shows a rapid decomposition process at the beginning of composting. This result is in accordance with a viewing of Cooperband (2000) and Atalia et al., (2015), stated that the smaller raw material size provides more access for microbes to decompose in the early stages of composting. However, the particle size of compost material that is too low also limits the entrance space for oxygen. If it is based on the ratio of $\mathrm{C} / \mathrm{N}, \mathrm{C}$-organic, $\mathrm{N}, \mathrm{O}$, and $\mathrm{K}$ obtained, it can be concluded that composting of rice straw does not require enumeration. The results of the same compost quality also mean that the material with a size of $50-55 \mathrm{~cm}$ is still an ideal size for composting with natural aeration.

\section{Conclusion}

The conclusions that can be drawn from this study are.

1) The use of local decomposers is able to provide good compost quality, in accordance with SNI 19-70302004 standard. Composting of the rice straw with the addition of a local decomposer 1 was able to provide a $\mathrm{C} / \mathrm{N}$ ratio up to 13.78 and local decomposers 2 up to 14.80. Local decomposition also has the same ability as commercial decomposers in decomposing rice straw.

2) The use of local decomposers gives the composting rate and the percentage of the compost mass reduction is higher than the control.

Muliarta, I. N., Agung, I. G. A. M. S., Adnyana, I. M., \& Diara, I. W. (2019). Local decomposer increase composting rate and produce quality rice straw compost. International Journal of Life Sciences, 3(1), 56-70.

https://doi.org/10.29332/ijls.v3n1.273 
3) Enumeration of rice straw does not provide different compost maturity and quality if it is compared to the treatment without being enumerated.

Based on the results of the study, composting of the rice straw should use a local decomposer. The research is needed to obtain local decomposers in a practical and easy way.

\section{Acknowledgments}

The author would like to thank the Head of the Laboratory of Plant Diseases, Faculty of Agriculture, Universitas Udayana, Dr. GN Alit Susanta Wirya, S.P, M.Agr and BPTP Bali who have given permission to use the collection of microbes owned. This research can be conducted thanks to funding assistance from the Directorate of Research and Community Service, Ministry of Research, Technology and Higher Education through the Doctoral Dissertation Research grant program for the budget year 2017/2018. 
References

Adawiyah, S. R., \& Mustari, K. (2017). Aplikasi isolat bakteri dari tpa tamangapa makassar dalam proses pengomposan sampah organik rumah tangga. celebes biodiversitas, 1(1). http://ojs.stkippi.ac.id/index.php/CB/article/view/97

Alemu, F. (2013). Isolation of Pseudomonas fluorescens from rhizospheric soil of faba bean and assessment of their Phosphate solubility: in vitro study, Ethiopia. Scholars academic journal of biosciences, 1(7), 346-351.

Alsanius, B. W., Blok, C., Cuijpers, W. J., França, S. C., Fuchs, J. G., Janmaat, L., ... \& van der Wurff, A. W. (2016). Handbook for composting and compost use in organic horticulture. BioGreenhouse COST Action FA 1105. http://orgprints.org/30598/

Ameen, A., Ahmad, J., \& Raza, S. (2016). Effect of pH and moisture content on composting of Municipal solid waste. International Journal of Scientific and Research Publications, 6(5), 35-37. https://pdfs.semanticscholar.org/8598/6be83e3483ce72c5d51f5de7a7cdf492c2ff.pdf

Atalia, K. R., Buha, D. M., Bhavsar, K. A., \& Shah, N. K. (2015). A review on composting of municipal solid waste.Journal of Environmental Science, Toxicology and Food Technology, 9, 20-29. https://pdfs.semanticscholar.org/69d3/625bf8871f0cd7b7f6c4de8650bcab8a9b2a.pdf

Aziz, R. A. (2018). Composting Technology and Impact of Compost on Arid Soil Biochemical Properties. http://www.sciencedomain.co/index.php/IJPSS/article/view/2408/4077

Bending, G. D., \& Turner, M. K. (1999). Interaction of biochemical quality and particle size of crop residues and its effect on the microbial biomass and nitrogen dynamics following incorporation into soil. Biology and fertility of soils, 29(3), 319-327. https://link.springer.com/article/10.1007/s003740050559

Binod, P., Sindhu, R., Singhania, R. R., Vikram, S., Devi, L., Nagalakshmi, S., ... \& Pandey, A. (2010). Bioethanol production from rice straw: an overview. Bioresource technology, 101(13), 4767-4774. https://doi.org/10.1016/j.biortech.2009.10.079

Bishop, P. L. (1983). Nitrogen variations during sludge composting. Biocycle, 24, 34-39. https://ci.nii.ac.jp/naid/80001726591/

Breitenbeck, G. A., \& Schellinger, D. (2004). Calculating the reduction in material mass and volume during composting. Compost \&cience \& utilization, 12(4), 365-371. https://doi.org/10.1080/1065657X.2004.10702206

Brewer, L. J., \& Sullivan, D. M. (2001). A quick look at quick compost stability tests. BioCycle, 42(1), 53-53. https://elibrary.ru/item.asp?id=6138421

Chan, E. S., Rudravaram, R., Narasu, M. L., Rao, L. V., \& Ravindra, P. (2007). Economics and environmental impact of bioethanol production technologies: an appraisal. Biotechnology and Molecular Biology Reviews, 2(1), 14-32. $\quad$ http://www.academicjournals.org/journal/BMBR/article-full-textpdf/3B685B910909

Chandna, P., Nain, L., Singh, S., \& Kuhad, R. C. (2013). Assessment of bacterial diversity during composting of agricultural byproducts. BMC microbiology, 13(1), 99. https://bmcmicrobiol.biomedcentral.com/articles/10.1186/1471-2180-13-99

Chheda, R., Verma, S., \& Nihar, D. (2016). Bio-Activator as a Solution of Biological Treatment Problems in Dairy Industries. Global Research and Development Journal for Engineering, March 2016: 103-105.

Cooperband, L. R. (2000). Composting: art and science of organic waste conversion to a valuable soil resource. Laboratory Medicine, 31(5), 283-290. https://doi.org/10.1309/W286-LQF1-R2M2-1WNT

Croyal, S., \& Sindhu, S. S. (2011). Composting of rice straw using different inocula and analysis of compost quality. M_icrobiol. J, 1, 126-138. http://docsdrive.com/pdfs/academicjournals/mj/0000/3405434054.pdf

de Bertoldi, M. D., Vallini, G. E., \& Pera, A. (1983). The biology of composting: a review. Waste Management \& Research, 1(2), 157-176. https://www.sciencedirect.com/science/article/pii/0734242X83900551

Dhal, G. C., Singh, W. R., Khwairakpam, M., \& Kalamdhad, A. S. (2012). Composting of water hyacinth using saw dust/rice straw as a bulking agent. International journal of environmental sciences, 2(3), 1223-1238. http://www.indianjournals.com/ijor.aspx?target=ijor:ijes\&volume=2\&issue=3\&article=007

Dilly, O., Bloem, J., Vos, A., \& Munch, J. C. (2004). Bacterial diversity in agricultural soils during litter decomposition. Appl. Environ. Microbiol., 70(1), 468-474. https://aem.asm.org/content/70/1/468.short

Muliarta, I. N., Agung, I. G. A. M. S., Adnyana, I. M., \& Diara, I. W. (2019). Local decomposer increase composting rate and produce quality rice straw compost. International Journal of Life Sciences, 3(1), 56-70. https://doi.org/10.29332/ijls.v3n1.273 
Erses, A. S., Onay, T. T., \& Yenigun, O. (2008). Comparison of aerobic and anaerobic degradation of municipal solid waste in bioreactor landfills. Bioresource technology, 99(13), 5418-5426. https://www.sciencedirect.com/science/article/pii/S0960852407009327

Gaind, S., \& Nain, L. (2011). Soil health in response to bio-augmented paddy straw compost. World J Agri Sci, 7(480), e8. https://pdfs.semanticscholar.org/461f/3d9c1137d50efd880e9681fbe60af671d1c3.pdf

Goyal, S., Singh, D., Suneja, S., \& Kapoor, K. K. (2009). Effect of rice straw compost on soil microbiological properties and yield of rice. Indian Journal of Agricultural Research, 43(4). https://pdfs.semanticscholar.org/7b8e/6df3a6508e0e0ffacb1747034976e0fc48b0.pdf

Harada, Y., Inoko, A., Tadaki, M., \& Izawa, T. (1981). Maturing process of city refuse compost during piling. Soil science and plant nutrition, 27(3), 357-364. https://doi.org/10.1080/00380768.1981.10431290

Herity, L. (2003). A study of the quality of waste derived compost in Ireland. Degree of Master of Science in Environmental Engineering, Queens University of Belfast, pp140. http://cre.ie/docs/quality_wastederived_compost160104.pdf

Hongoh, Y., \& Toyoda, A. (2011). Whole-genome sequencing of unculturable bacterium using whole-genome amplification. In High-Throughput Next Generation Sequencing (pp. 25-33). Humana Press, Totowa, NJ. https://doi.org/10.1007/978-1-61779-089-8_2

Kadir, A. A., Azhari, N. W., \& Jamaludin, S. N. (2017). Evaluation of physical, chemical and heavy metal concentration of food waste composting. In MATEC Web of Conferences (Vol. 103, p. 05014). EDP Sciences. https://www.matecconferences.org/articles/matecconf/abs/2017/17/matecconf_iscee2017_05014/matecconf_iscee2017_05 014.html

Kalatzi, E., Sazakli, E., Karapanagioti, H. K., \& Leotsinidis, M. Composting of brewery sludge mixed with different bulking agents. http://uest.ntua.gr/cyprus2016/proceedings/pdf/Kalatzi_et_al_Composting_of_brewery_sludge_mixed_wi th_different_bulking_agents.pdf

Kapri, A., \& Tewari, L. (2010). Phosphate solubilization potential and phosphatase activity of rhizospheric Trichoderma spp. Brazilian Journal of Microbiology, 41(3), http://www.scielo.br/scielo.php?pid=S1517-83822010005000001\&script=sci_arttext\&tlng=pt

Lal, S., \& Tabacchioni, S. (2009). Ecology and biotechnological potential of Paenibacillus polymyxa: a minireview. Indian Journal of Microbiology, 49(1), 2-10. https://doi.org/10.1007/s12088-009-0008-y

Larney, F. J., Olson, A. F., Carcamo, A. A., \& Chang, C. (2000). Physical changes during active and passive composting of beef feedlot manure in winter and summer. Bioresource Technology, 75(2), 139-148. https://doi.org/10.1016/S0960-8524(00)00040-7

Lee, Y. (2016). Various microorganisms' roles in composting: A review. APEC Youth Scientist Journal. 8: 11, 15. http://amgs.or.kr/New/common/journal/vol8/vol8_1_no.2.pdf

Liu, D., Lian, B., \& Dong, H. (2012). Isolation of Paenibacillus sp. and assessment of its potential for enhancing mineral weathering. Geomicrobiology Journal, 29(5), 413-421. https://doi.org/10.1080/01490451.2011.576602

Lok, C. (2015). Mining the microbial dark matter. Nature News, 522(7556), 270. https://doi.org/10.1038/522270a

Lopes-Assad, M. L., Avansini, S. H., Rosa, M. M., De Carvalho, J. R., \& Ceccato-Antonini, S. R. (2010). The solubilization of potassium-bearing rock powder by Aspergillus niger in small-scale batch fermentations. Canadian journal of microbiology, 56(7), 598-605. http://www.nrcresearchpress.com/doi/abs/10.1139/w10-044

Makan, A., Assobhei, O., \& Mountadar, M. (2013). Effect of initial moisture content on the in-vessel composting under air pressure of organic fraction of municipal solid waste in Morocco. Iranian journal of environmental health science \& engineering, 10(1), 3. https://doi.org/10.1186/1735-2746-10-3

Matthews, S., \& Kamal, E. A. (2015). Identification of rice straw degrading microbial consortium. Journal of Tropical Agriculture and Food $119-127$. https://www.researchgate.net/profile/Stella_Matthews/publication/313769992_Identification_of_rice_str aw_degrading_microbial_consortium/links/58a572fca6fdcc0e076500f1/Identification-of-rice-strawdegrading-microbial-consortium.pdf 
Michel Jr, F. C., Pecchia, J. A., Rigot, J., \& Keener, H. M. (2004). Mass and nutrient losses during the composting of dairy manure amended with sawdust or straw. Compost Science \& Utilization, 12(4), 323-334. https://doi.org/10.1080/1065657X.2004.10702201

Mitri, S., \& Richard Foster, K. (2013). The genotypic view of social interactions in microbial communities. Annual review of 247-273. https://www.annualreviews.org/doi/abs/10.1146/annurev-genet-111212-133307

Nazhad, M. M., Ramos, L. P., Paszner, L., \& Saddler, J. N. (1995). Structural constraints affecting the initial enzymatic hydrolysis of recycled paper. Enzyme and microbial technology, 17(1), 68-74. https://doi.org/10.1016/0141-0229(94)00057-X

Nur, H. S., \& Meryandini, A. (2009). Pemanfaatan Bakteri Selulolitik dan Xilanolitik yang Potensial untuk Dekomposisi Jerami Padi. Jurnal Tanah Tropika, 14(1), https://www.ingentaconnect.com/content/doaj/0852257x/2009/00000014/00000001/art00010

Nuraini. (2009). Pembuatan Kompos Jerami Menggunakan Mikroba Perombak Bahan Organik. Buletin Teknik Pertanian, 14 (1): 23-26.

Olson, J. S. (1963). Energy storage and the balance of producers and decomposers in ecological systems. Ecology, 44(2), 322-331. https://doi.org/10.2307/1932179

Otieno, N., Lally, R. D., Kiwanuka, S., Lloyd, A., Ryan, D., Germaine, K. J., \& Dowling, D. N. (2015). Plant growth promotion induced by phosphate solubilizing endophytic Pseudomonas isolates. Frontiers in Microbiology, 6, 745. https://doi.org/10.3389/fmicb.2015.00745

Palanivell, P., Susilawati, K., Ahmed, O. H., \& Majid, N. M. (2013). Compost and crude humic substances produced from selected wastes and their effects on Zea mays L. nutrient uptake and growth. The Scientific World Journal, 2013. http://dx.doi.org/10.1155/2013/276235

Parmar, K. B., Mehta, B. P., \& Kunt, M. D. (2016). Isolation, characterization and identification of potassium solubilizing bacteria from rhizosphere soil of maize (Zea mays). Int J Sci Env Technol, 5(5), 3030-3037. http://www.ijset.net/journal/1259.pdf

Peraturan Menteri Pertanian Nomor 70/Permentan/SR.140/10/2011 Tentang Pupuk Organik, Pupuk Hayati Dan Pembenah Tanah.

Ponnamperuma, F. (1984). Straw as a source of nutrients for wetland rice; Organic matter and rice. International Rice Research Institute, Manila, Philippines, 117-136.

Rishell, E. (2013). Backyard Composting.Virginia Cooperative Extension-Publication Hort-49P. Virginia Polytechnic Institute and State University.

Roman, P., Martinez, M. M., \& Pantoja, A. (2015). Farmer's Compost Handbook: Experiences in Latin America. FAO Rome. ISBN: 978-92-5-107845-7.

Sadik, M. W., El Shaer, H. M., \& Yakot, H. M. (2010). Recycling of agriculture and animal farm wastes into compost using compost activator in Saudi Arabia.J. Int. Environ. Appl. Sci, 5(3), 397-403. http://citeseerx.ist.psu.edu/viewdoc/download?doi=10.1.1.303.82\&rep=rep1\&type=pdf

Saini, J. K., Saini, R., \& Tewari, L. (2015). Lignocellulosic agriculture wastes as biomass feedstocks for secondgeneration bioethanol production: concepts and recent developments. 3 Biotech, 5(4), 337-353. https://doi.org/10.1007/s13205-014-0246-5

Salih, H. M., Yahya, A. I., Abdul-Rahem, A. M., \& Munam, B. H. (1989). Availability of phosphorus in a calcareous soil treated with rock phosphate or superphosphate as affected by phosphate-dissolving fungi. Plant and soil, 120(2), 181-185. https://doi.org/10.1007/BF02377067

Sari, S. V., Qayim, I., \& Hilwan, I. (2016). Litter Decomposition Rate of Karst Ecosystem at Gunung Cibodas, Ciampea Bogor Indonesia. Journal of Tropical Life Science, 6(2), 107-112. http://www.jtrolis.ub.ac.id/index.php/jtrolis/article/view/572

Sarwar, G., Hussain, N., Schmeisky, H., Muhammad, S., Ibrahim, M., \& Safdar, E. (2007). Use of compost an environment friendly technology for enhancing rice-wheat production in Pakistan. Pak. J. Bot, 39(5), 15531558. http://www.pakbs.org/pjbot/PDFs/39(5)/PJB39(5)1553.pdf

Sethi, S., Datta, A., Gupta, B. L., \& Gupta, S. (2013). Optimization of cellulase production from bacteria isolated from soil. ISRN biotechnology, 2013.

http://downloads.hindawi.com/journals/isrn.biotechnology/2013/985685.pdf

Muliarta, I. N., Agung, I. G. A. M. S., Adnyana, I. M., \& Diara, I. W. (2019). Local decomposer increase composting rate and produce quality rice straw compost. International Journal of Life Sciences, 3(1), 56-70. https://doi.org/10.29332/ijls.v3n1.273 
Shruti, A. S., \& Malik, D. K. (2015). Lignocellulose biomass degradation by microbial consortium isolated from harvested rice field. Int. J. Curr. Microbiol. App. Sci, 4(9), 274-280. https://pdfs.semanticscholar.org/db0b/1bcd6f8bf604469fce14e032bb18223166a5.pdf

Sirisena, D. M., \& Manamendra, T. P. (1995). Isolation and characterization of cellulolytic bacteria from decomposing rice straw. Journal of the National Science Foundation of Sri Lanka,23(1). https://www.researchgate.net/profile/Dassanayake_Sirisena/publication/237482373_Isolation_and_char acterization_of_cellulolytic_bacteria_from_decomposing_rice_straw/links/543614ba0cf2dc341db2db94.pd $\mathrm{f}$

Sitepu, R. B., Anas, I., \& Djuniwati, S. (2017). Pemanfaatan Jerami Sebagai Pupuk Organik Untuk Meningkatkan Pertumbuhan Dan Produksi Padi (Oryza sativa). Buletin Tanah dan Lahan,1(1), 100-108. http://jagb.journal.ipb.ac.id/index.php/btanah/article/view/17698

Sondang, Y., Anty, K., \& Alfina, R. (2014). The Influence of Bioactivator Cattle Feces Against The Length of Composting and C/N Ratio from Three Kind of Organic Material. International Journal on Advanced Science, Engineering and Information Technology, 4(4), 278-281. http://dx.doi.org/10.18517/ijaseit.4.4.416

Stewart, E. J. (2012). Growing unculturable bacteria. Journal of bacteriology, 194(16), 4151-4160. http://dx.doi.org/10.1128/JB.00345-12

Streminska, M. A., \& Raviv, M. (2016). 3 Microbiology of the composting process. Handbook for Composting and Compost Use in Organic 45. https://library.wur.nl/WebQuery/wurpubs/fulltext/375218\#page $=45$

Strom, P. F., \& Finstein, M. S. (1994). New Jersey's Manual on Composting Leaves and Management of other Yard Trimmings. Department of Environmental Sciences, Cook College, New Jersey Agricultural Experiment Station, Rutgers University.

Sundberg, C. (2005). Improving compost process efficiency by controlling aeration, temperature and $p H$ (Vol. 2005, No. 103). http://pub.epsilon.slu.se/id/document/650

Tallapragada, P., \& Gudimi, M. (2011). Phosphate solubility and biocontrol activity of Trichoderma harzianum. Turkish journal of Biology, 35(5), 593-600. https://journals.tubitak.gov.tr/biology/abstract.htm?id=11990

Tiquia, S. M., Richard, T. L., \& Honeyman, M. S. (2002). Carbon, nutrient, and mass loss during $\begin{array}{llll}\text { composting. Nutrient } \quad \text { Cycling } & \text { Agroecosystems, 62(1), }\end{array}$ https://doi.org/10.1023/A:1015137922816

Tsigarida, E., Boziaris, I. S., \& Nychas, G. J. E. (2003). Bacterial synergism or antagonism in a gel cassette system. Appl. Environ. Microbiol., 69(12), 7204-7209. https://doi.org/10.1128/AEM.69.12.72047209.2003

Tuomela, M., Vikman, M., Hatakka, A., \& Itävaara, M. (2000). Biodegradation of lignin in a compost environment: a review. Bioresource technology, 72(2), 169-183. https://doi.org/10.1016/S09608524(99)00104-2

Wang, C. T., Lee, Y. C., \& Liao, F. Y. (2015). Effect of composting parameters on the power performance of solid microbial fuel cells. Sustainability, 7(9), 12634-12643. https://doi.org/10.3390/su70912634

Watanabe, T., Man, L. H., Vien, D. M., Khang, V. T., Ha, N. N., Linh, T. B., \& Ito, O. (2009). Effects of continuous rice straw compost application on rice yield and soil properties in the Mekong Delta. Soil science and plant nutrition, 55(6), 754-763. https://doi.org/10.1111/j.1747-0765.2009.00424.x

Weselowski, B., Nathoo, N., Eastman, A. W., MacDonald, J., \& Yuan, Z. C. (2016). Isolation, identification and characterization of Paenibacillus polymyxa CR1 with potentials for biopesticide, biofertilization, biomass degradation and biofuel production. BMC microbiology, 16(1), 244. https://doi.org/10.1186/s12866-0160860-y

Wichuk, K. M., \& McCartney, D. (2010). Compost stability and maturity evaluation-a literature review. Canadian Journal of Civil Engineering, 37(11), 1505-1523. https://doi.org/10.1139/L10-101

Wu, D. L., Liu, P., Luo, Y. Z., Tian, G. M., \& Mahmood, Q. (2010). Nitrogen transformations during co-composting of herbal residues, spent mushrooms, and sludge. Journal of Zhejiang University SCIENCE B, 11(7), 497-505. https://doi.org/10.1631/jzus.B0900271

Yaacob, S. Z., Abdullah, N., \& Abdullah, L. C. Potential of trichoderma harzianum as cellulose biodegrader in biocomposting of paddy straw. http://www.akademiabaru.com/doc/ARMSV39_N1_P8_13.pdf 
Zhao, H., Yu, H., Yuan, X., Piao, R., Li, H., Wang, X., \& Cui, Z. (2014). Degradation of lignocelluloses in rice straw by BMC-9, a composite microbial system.J. Microbiol. Biotechnol,24(5), 585-591. https://pdfs.semanticscholar.org/2dd6/d2b8e068d3a6cfe067dd28b4761ded75e33f.pdf 


\section{Biography of Authors}

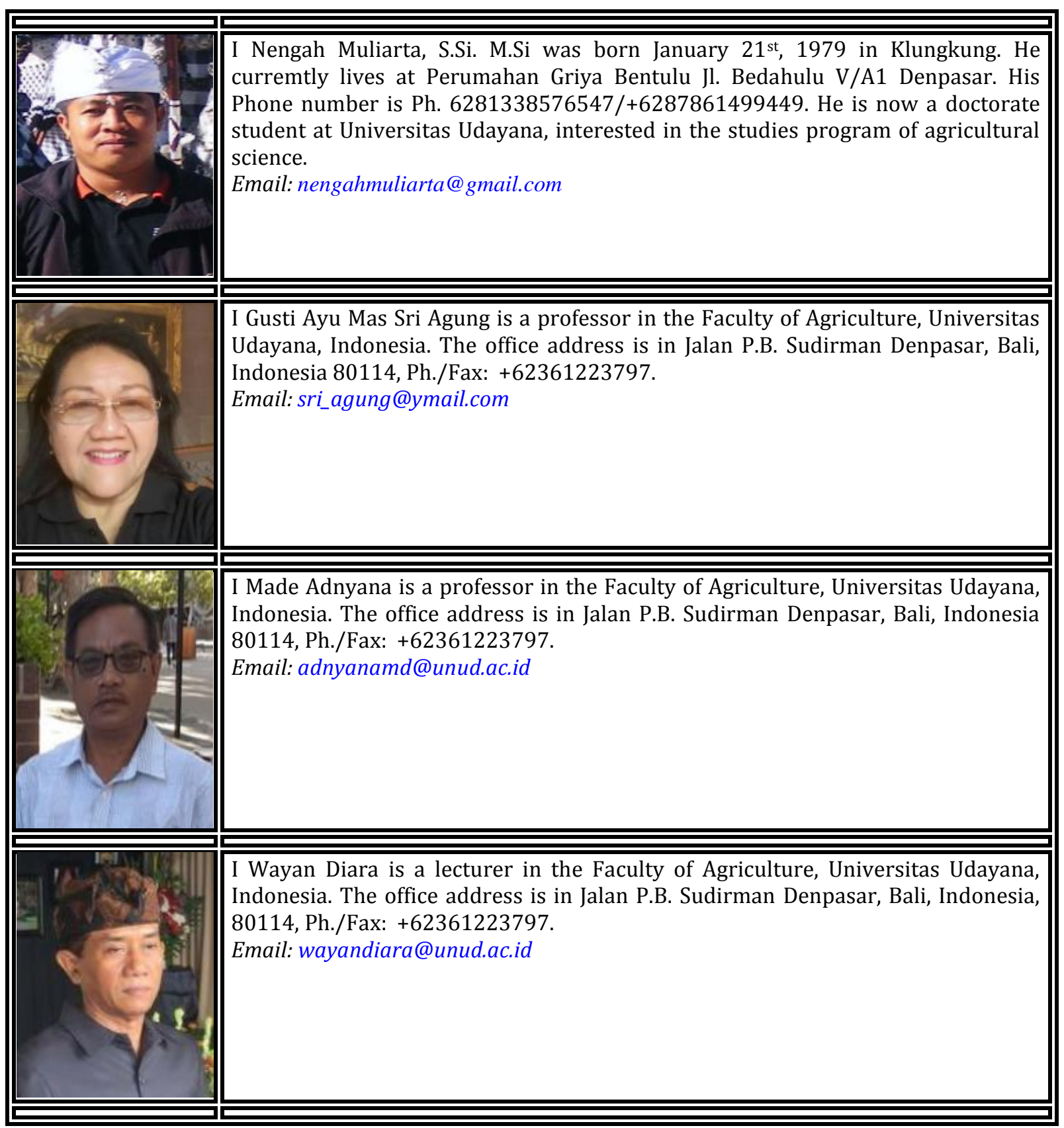

